\title{
Trafficking of Nigerian Women and Young Girls for Sex Trade and Forced Servitude in Europe
}

\author{
EMMANUEL MADUFORO (PhD) \\ Former Research Candidate, School Of Law, University of Manchester \\ M13 9PL,Oxford Road, Manchester, UK
}

\begin{abstract}
Human trafficking is endemic and a serious global problem. It is a multidimensional human rights violation that centers on the act of sex exploitation, profit making, physical and psychological harm to victims. Apart from that, trafficking in persons is a lucrative business and recent data shows that human trafficking is a $\$ 32$ billion industry. Statistics have shown that as many as 3 million people are trafficked and enslaved annually mainly in Europe. Without prevarication, human trafficking is a clandestine in nature and victims are sexually exploited, physically assaulted, forcefully enslaved and maltreated. Unfortunately, it has serious socio-cultural and human rights implications, and health related problems. Nigeria is a country of origin, destination, recruitment, transit and Italy, Netherlands, Spain and France are receiving and destination countries. Surprisingly, the Nigerian government has not done enough to eradicate the phenomenon. This paper therefore articulates the insidious nature of human trafficking and the harrowing experiences of Nigeria women and young girls in Europe. The work is important because it made germane recommendations and provided ways on how affected countries like Nigeria and Italy can handle and manage the menace effectively and socially. For example, the problem of trafficking of Nigerian women and young girls for sex trade and forced labour in Europe is not only demeaning but also a violation of victim's right to life and freedom of movement. To illuminate the problem, the paper highlights the push and pulls effects and the human rights implications victims experienced. The paper argued that the Nigerian government is not doing enough to eradicate the trafficking of Nigeria women for sexual exploitation and forced labour in Europe. The paper concludes with germane suggestions and recommendations on how best to mitigate the problem of human trafficking not only in Nigeria but also in some European countries.
\end{abstract}

Keywords:Human trafficking and its root Causes, Socio-cultural implications, and failure of Nigerian government.

DOI: $10.7176 / \mathrm{JAAS} / 73-03$

Publication date:June $30^{\text {th }} 2021$

\section{INTRODUCTION}

Ever since the existence of human civilization on the planet, human beings have continued to migrate from one place to another in search of food, jobs and safe environment while crossing local, national and international frontiers. This is called labour migration. It is all about economic and social mobility activity that benefits millions of people globally. So migration in particular is not a new phenomenon. But in recent times, it has become a global concern because it has snowballed into human trafficking for sexual exploitation and also as a modern form of slavery. Human trafficking it must be understood involves the exploitation of low-wage workers and vulnerable women and young girls from poor homes.

The International Organization for Migration (IOM) had maintained that migration is a population movement, encompassing any kind of movement of people, whatever its length, composition and causes; it includes migration of refugees, displaced persons, economic migrants, and persons moving for other purposes ${ }^{1}$. No doubt, the activities of traffickers and the process of migration essentially differ in the way it is being conducted; however, there are growing concerns that labour migration has become part and parcel of human trafficking which involves sexual exploitation of women, young girls and migrant workers. Human Trafficking we musk know has become a global problem of great magnitude ${ }^{2}$. The IOM and NGOs like the Solidarity Centre seems not to be comfortable with the way migration processes are conducted globally. Arising from this suspicion, the Solidarity Centre asserted that with the mandate to protect the rights of migrant workers, that trafficking can occur at any point in time. The IOM also expressed the same fear and argued that there is need to approach the trafficking in persons from the overall context of managing migration. Albeit, it is difficult to say that the activities of one phenomenon presupposes the operation of the other, however, it is evident today that migration and trafficking in persons appears to be interconnected given the forces of globalization and economic demands of migrants and unsuspecting trafficked victims. No doubt, migration with and across national borders

\footnotetext{
${ }^{1}$ International Organisation for Migration (IOM 2013) available at. http://www.iom.int/cms/en/sites/iom/home/about,igration/key-migrationterms-1-html.

${ }^{2}$ Zimmerman C, and Kiss L. (2017) Human Trafficking and exploitation: A Global Health Concern. PLOS Medicine. Vol. 14(11). Available at. www.HUMAN\%20Trafficking/pmed.1002437.pdf. Accessed 28/07/2019.
} 
has been economic and social mobility strategy that has benefited millions of people around the world. But due to the nature of man, it is no longer a mere movement in search of food and good life, or social mobility strategy, but one full of mischievous intentions, manipulative antics and exploitative in nature. The form of migration in our society today is no longer free movement of migrant, rather it is one controlled by some disgruntled elements that are desperate and want to capitalize on vulnerability of women, porous borders and weak international legal instruments on trafficking to make monetary gain for their own selfish interest. This reason therefore isolated social and economic migration from human trafficking. It is so because the latter involves exploitation, physical abuse, use of force, fraud, and crime committed across borders while the former is somewhat devoid of criminal activities, but socially and economically induced.

The criminal activities and sexual exploitation of women and young girls that characterized global human trafficking affects major European countries and some African countries today. The perpetrators or otherwise called rogues or enemies of progress have become formidable because of the lucrative nature of human trafficking. Their actions and modus operandi violate human rights and the sanctity of human life. For example, women and young girls recruited for labour related purposes are in turn forced into prostitution, and dehumanizing activities. Unfortunately, these innocent women and young girls do not have all it takes to seek for their freedom until they pay the last penny. Surprisingly, the international legal framework against human trafficking and modern day slavery is weak and lacks effective sanctions. At this juncture therefore, there is urgent need for international law and UN legal framework against human trafficking should be more decisive and proactive. Also, Member States to Protocol against Trafficking in Persons should enforce trafficking laws purely according to international standard practice because human trafficking is an international crime or crime of modern slavery. For instance, sexual exploitation forced labour, servitude, and other forms of modern day slavery should carry stiff penalty. But this is not so. As a result, this has negatively increased sex trafficking, exploitative labour and immigration problems.

It is against this background therefore, that trafficking is termed as inhuman, exploitative, violent, abuse of unsuspecting women and young girls by the criminal gangs and the economically powerful but morally debased individuals in our society. Its prevalence is not only because of globalization, but also its lucrative nature, poor border checks, and lack of proactive measures from recruiting countries and destination countries ( Nigerian government and government of Italy and Netherland).

Based on this development, the United Nations Convention on Transnational Organized Crime (UNCTOC) and its supplementary protocol i.e. Protocol to Prevent, Suppress, Punish Trafficking in Persons also known as Palermo Protocol ${ }^{1}$, thus describes human trafficking as "transnational organized crime". The Convention in fact considers human trafficking as crime with enormous socio-cultural consequences and with the substantial part of this crime as a preparation, planning, exploitation, manipulation or control of victims ${ }^{2}$. Sometimes, it is committed in one state but involved an organized criminal gang that engages in criminal activities in more than one state ${ }^{3}$. Like money laundering, advanced fee fraud, cyber crime, illicit trade in arms and narcotics, human trafficking has become a worrisome development in our contemporary society ${ }^{4}$.

\section{DEFINING HUMAN TRAFFICKING}

This paper is not interested in giving too many definitions of human trafficking because there are too many competing definitions out there and for the purpose of this paper we shall adopt a definition that best describe all facets of trafficking in persons in the world presently. Apart from that, no definition of human trafficking is universal and encompassing; however, attempt is made to give a working definition that will direct our critical analysis, arguments and our recommendations in this work. The working definition will assist us illuminate the socio-cultural, political, economic and legal undertone of trafficking in persons.

To start with, Meirs ${ }^{5}$, Ould ${ }^{6}$, and Bales ${ }^{7}$, conceptualized the phenomenon, human trafficking as a modern form of slavery while others termed it as a new slavery referring to the complete control of a person for economic exploitation by violence or the threat of harm.

It has also been defined from criminological point of view and because of much literature on the criminogenic effects of globalization, human trafficking is termed as an exemplar of the globalization of crime. The social, cultural and technological conditions of globalization i.e. the intensity of worldwide interconnectedness and the velocity of global flows of people and ideas, it is argued that globalization create new

\footnotetext{
${ }^{1}$ See UNCTOC Report 2000.

${ }^{2}$ Guruam S. and Sing Harbilas opt cit.

${ }^{3}$ Ibid.. p. 485.

${ }^{4}$ Poulin. B (2004) Globalization and Sex Trade, Trafficking and Commodification of Women and children, ca. Women's stud., 22 38-43.

${ }^{5}$ Miers, S. (2003)Slavery in the Twentieth Century; The Evolution of a Global Problem. Walnut Creek, CA: Alta Mira Press.

${ }^{6}$ Ould, D. (2004) Trafficking and International Law in C. Van Den Anker (ed). The Political Economy of New Slavery. Basingstoke: Palgrave Macmillan.

${ }^{7}$ Bales, K. (2005) Understanding Global slavery, Berkeley University of California Press. p. 462
} 
and favourable contexts for crime ${ }^{1}$. Another definition coalesced human trafficking around contested positions on issues of prostitution, individual agency, and consent. This definition is anchored on the notion that trafficking is synonymous with the traffic of women for commercial sex exploitation ${ }^{2}$. Bruinsma maintained that the role of criminally sophisticated, transnational organized crime has been a driving force behind the highly prohibited trade of smuggling and trafficking of unauthorized migrants or asylum seekers ${ }^{3}$.

Unfortunately these definitions tend not to capture the concrete status of what human trafficking entails. However, human trafficking, it is said must have the following elements for it to qualify as trafficking.

- Recruitment, transportation, reception, transfer or harbouring of persons

- There must threats, use of force, fraud, coercion, abuse of power, abduction, deception and being vulnerable, and profit/benefits to the person controlling victims.

- There must be desired goals or exploitation that tends to involve the removal of victims' organs, slavery, forced labour or services or involuntary prostitution and other different kinds of sexual enslavement.

Against this backdrop, a working definition given by the United Nations Protocol is chosen for this paper because it articulates the arguments and objectives of this work.

The UN General Assembly Resolution 55/25 of $15^{\text {th }}$ November 2000, Article 3 of the United Nations Protocol to Prevent, Suppress and Punish Trafficking in Persons especially Women and Children ${ }^{4}$, defined trafficking in persons as the recruitment, transportation, transfer, harbouring, or receipt of persons, by means of the threat or use of force or other forms of coercion, of abduction, of fraud, of deception, of the abuse of power, or of a position of vulnerability or of the giving or receiving of payments or benefits to achieve the consent of a person having control over another person for the purpose of exploitation" 5 "Exploitation shall include, at a minimum, the exploitation of the prostitution of others or other forms of sexual exploitation, forced labor or services, slavery or servitude or the removal of organs ${ }^{6}$. However, consent it must be understood is not

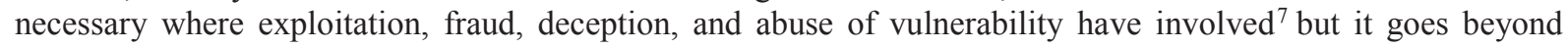
consent because at the long run it involves abuse and exploitation of unsuspecting women and young girls.

As a result of definition problems therefore, we have decided to go with a working definition provided by the UN Palermo Protocol adopted on 15 November 2000 in New York. The reason is that Palermo Protocol has international law coverage of what human trafficking is and this is based on a combination of three important elements. First is the process of trafficking which comprises recruitment, transportation, transfer, and habouring. Second, is the means in which the act is executed i.e. threat, coercion, force, abduction, fraud, deception, abuse of power and finally, the purpose of the act of trafficking which is exploitation, financial benefits, forced labour and servitude, slavery and removal of victims organs ${ }^{8}$. No doubt the above definition though not exhaustive, however explains and analyses what human trafficking entails and this is why it is the adopted definition for this paper.

It is true that some anti-human trafficking strategies adopted by some countries to reduce scourge have not yielded significant results probably because there are no collective effort or that the international legal instruments and national legislations of countries has been compromised and as such there is no political will to enforce and punish offenders. Countries like Nigeria, Gambia, Senegal, Sierra Leone and some other countries have not made encouraging efforts towards the eradication of human trafficking and sex trade. But before we discuss other salient issues in this paper, let us examine the root causes of human trafficking in Nigeria.

\section{ROOT CAUSES OF HUMAN TRAFFICKING}

\section{THE PUSH FACTOR}

Since our concentration in this paper is to analyze the trafficking of Nigerian women and young girls to Europe for sex trade and forced labour, and its attendant social-economic implications, and health related problems, it is imperative also to highlight reasons why trafficking in persons exists in our society. It is also important in this paper to explicate those factors that push victims to fall prey to traffickers and why oil-rich nation like Nigeria is the recruiting ground and destination country for trafficking of women and young girls for sex trade in Europe.

To start with, James and Atler maintained that the push factor strengthens the vulnerability of the demerit of

\footnotetext{
${ }^{1}$ Maggy, L,. (2007) Human Trafficking, William Publishing, Oregon USA.p.3

2 . Maggy, L, (2007) Human Trafficking, William Publishing, Oregon USA.p.3 p.4.

${ }^{3}$ Bruinsma et al (1999) Organized Crime and trafficking Women from Eastern Europe in the netherlands', Transnational Organized crime, 4 pp. 105-118.

${ }^{4}$ The United Nations Protocol to Prevent, Suppress and Punish Trafficking in Persons especially Women and Children. The UN General Assembly Resolution 55/25 of $15^{\text {th }}$ November 2000. Available at. Https:/www.ohchr.org/en/professionalinterest/pages/protocoltraffickingin persons.aspx.

${ }^{5}$ Ibid.

${ }^{6}$ Ibid.

${ }^{7}$ Thozama Mandisa L, and Lanier, M (2012) An Integrated Theoretical Framework to Describe Human Trafficking of Young Women and Girls for Involuntary Prostitution. Journal of public Health-Social and Behavioral Health. www.intechopen.com. Accessed 20/06/2018

${ }^{8}$ Perera, A. (2011), Human Trafficking, New Delhi: Global Vision Publishing House India.
} 
social groups to trafficking while the demand for commercial sex is derived from the pull factors ${ }^{1}$. Sassen argued that the push factors fall into a wider aspect that has to do with the economic impacts of globalization which drives people to move from one place to another in search of opportunities to make a better living ${ }^{2}$. The US, Department of States in its report 2006 informed that these push factors includes poverty, unemployment, illiteracy and ignorance, corruption in the public and private sectors of the government, domestic violence, armed conflict, inter tribal clashes, displacement and marginalization of women in society ${ }^{3}$. Apart from poverty, unemployment etc, katerere and Hosken added that traditional practice such as early marriage, broken homes or family ties ${ }^{4}$ and absence of law and order in societies also motivate trafficking ${ }^{5}$. Troung and Angeles grouped the push factors into three categories. The first is motivational factor which relates to socio-cultural factors such as low level of education, child labour and early marriage. The second category relates to economic factors which comprises of the inequalities of wealth between the rural and urban area and the desire to escape from poverty and finally the political and juridical factors that consist of the lack or absence of enforceable legislations and failure of government policy ${ }^{6}$.

Economists and social scientists believed that the push factors are prevalent in underdeveloped countries where economic institutions are weak, not inclusive as to allow for incentives of job and education opportunities, social welfare and entrepreneurship to thrive. It can be observed that the economic institutions in the underdeveloped countries like Nigeria, Mali, Senegal and Ghana have performed abysmally low because the institutions are extractive and controlled by the narrow elite. It breeds poverty, unemployment, illiteracy, lack of access to entrepreneur skills acquisition, mismanagement of resources, and inadequate health care system. For example, extreme poverty, unemployment, discrimination of Nigerian women, insecurity, high illiteracy level are dominant factors that motivates trafficking of Nigerian women and young girls for sexual exploitation and cheap labour abroad. Others factors are oppression, child abuse and domestic violence against women. The abandoning of these hapless women by their families reflects prejudiced socio-cultural practices are part and parcel of push factors that make these women and young girls' targets of kidnapping by criminal gangs.

Poulin argued that it is the quest for better life that exposes these women and young girls to fall prey to trafficking ${ }^{7}$. It is therefore striking to note that the quest for better life, and failure of the state to provide enduring social and economic opportunities for her citizens particularly these vulnerable young women and girls that create room for sex trafficking and forced labour. This problem undermines human dignity and the dignity of labour as exposed by karl Marx in his Communist manifesto ${ }^{8}$. Labour for Marx ought to be when it is free and an expression of life. Labour creates man and gives man his essence and it is an activity and not a commodity. But traffickers have turned women as commodity to be exploited and abused for monetary benefits.

According to the Sisters of Notre Dame de Namur's report $2014^{9}$, traffickers prey on people that are vulnerable and economically disadvantaged families. For example, people in the oil producing areas of Niger Delta of Nigeria. These women have lost the source of their livelihood to extensive oil exploitation. And these traffickers capitalize on vulnerability of these women and young girls to promising them prosperity and good jobs in Europe. Strikingly, these promises are unrealistic and absolutely a ploy to traffic them abroad for sex trade and exploitation.

Again, political instability, religious crisis, armed conflict and crime rate in Nigeria seems to have triggered human trafficking and sexual exploitation of Nigerian women. The recent Boko Haram attacks in the North East Nigeria and religious crisis in other parts of Northern region, kidnapping, herdsmen attacks on farm owners contributed largely to the push factors. The aftermath effects have been huge. It has caused tremendous displacement of families and serious insecurity challenges, instability and high crime rate. This development has increased the population of people moving from one place to another in search of better life either abroad or neighbouring countries. Young women and girls from poor families who are victims of displaced homes fall into the waiting hands of traffickers and kidnappers. It is therefore shocking to note that, some of these kidnapped

\footnotetext{
${ }^{1}$ James, C., and Atler, S. (2003) trafficking of young Women in Arvanitakis (ed.) Highly Affected Rarely

Considered; The International Youth parliament Commission's Report on the Impacts of Globalization on Young

People'. Oxfam International Parliament Sydney 71-82.

${ }^{2}$ Sassen, S. (2002) Women's burden: Counter-geographies of Globalization and the Feminization of Survival. Nordic Journal of international Law 71 (2) 255-274.

${ }^{3}$ See The U.S Department of State (2006) Trafficking in Persons Report. Available at. http://www.state.gov/j/tip/rls/tiprpt/2006. Accessed 23/07/2019.

Katerere, F. (2007) Human Traffickers Thrive in Mozambique. The Citizen. Available at. http://www.citizen.co.za/index/article.aspx?pDesc=35379,1,22. Accessed 23/07/2019

${ }^{5}$ Hosken, G. (2007) Human Trafficking a Huge problem in SA The Independence.

${ }^{6}$ Truong, T.,and Angels, M. (2005) Searching for the Best Practices to Counter Human Trafficking in Africa; A focus on Women and

Children. UNESCO: Project to Fight Human trafficking in Africa.

${ }^{7}$ Poulin, R (2004). Globalization and Sex, Trade: Trafficking and Commodification of Women and Children Ca. Women's Stud., 22 38-43

${ }^{8}$ Marx, K and Engels, F. (1848) The Communist. Manifesto. Jaico Publishing House.

${ }^{9}$ Sisters of Notre dame de Namur (2014). The Causes of Trafficking. In Action for Justice Columbia: The Author.
} 
children and young girls are used by terrorists as suicide bombers today while Christians kidnapped by the insurgents are forced to denounce their faith and forced by the terrorists to marry them. At this juncture, one is quick to say that insecurity and community strife motivates human trafficking and sex trade in Nigeria.

Another contributory factor is the structure of our socio-cultural milieu and the place of women in Nigeria. Without equivocation, most women in our society are discriminated and sexually abused, exploited and psychologically traumatized. For example, Nigeria women who aspire to leadership position have directly or indirectly been politically and socially discriminated, excluded in the scheme of things unlike their counterparts in other countries like Liberia, Argentina, and United Kingdom. Though the present government is trying to include more women in leadership position, it is evident that greater Nigeria women are still being excluded from sensitive political positions. This development is unhealthy to our socio-cultural milieu and if urgent steps are not taken more negative effects will lead to more women being trafficked and exploited. For example, women and young girls are running away from home for a better life either because they were denied education opportunities or have been sexually exploited, or forced into early marriage.

Early child marriage has become a serious global challenge in developing countries particularly in Nigeria. The remote causes of early child marriage include financial uncertainty, religious belief, cultural expectation, family alliance, kidnapping, ignorance, traditional practice and community practice ${ }^{1}$. Financial uncertainty is where the parents of the girl child are faced with financial difficulties and there is no money to send their girl child to school. These girls upbringing becomes expensive and a burden to the family. Some religious beliefs do not condemn under age marriage or early child marriage and as such some families capitalize on this religious sentiment to marry their girls off early. Not long ago in Lagos Nigeria a girl was almost raped at a hotel in Nigeria by a 40 year old man who offered to help her while she was running away from her sister's house to avoid being abused by neighbours in the same compound ${ }^{2}$. Many unlucky ones have been drugged and ganged raped, and physically assaulted. Here the Nigerian government bears a great deal of responsibility to minimize the growing trend of girl child marriage. Girl-Child Marriage in the Nigerian Society, Causes, Impacts and Mitigating Strategies

Although the economic, socio-cultural and political issues are dominant factors of push factor, however, it is difficult to say why a rich oil nation like Nigeria should be a recruiting and destination country for human trafficking. The shocking aspect is that most women and young girls from the oil producing regions are victims of human trafficking and sexual exploitation abroad. The reason is that the country's oil resources that generate about $\$ 136$ billion a year have not been used to provide employment opportunities and education opportunities for these women. For example, women and young girls from Edo, Delta, Akwa Ibom and Imo state where oil is derived are targets. Moreover, it is a fact that the oil producing region records the highest number of women and young girls trafficked to Europe and other parts of African countries for sex trade and forced labour. Communities where these women hail from have consistently been marginalized, impoverished, ecologically handicapped and infrastructurally underdeveloped. Some of them who are fisherwomen cannot make ends meet because the waters are polluted and aquatic life and sea foods destroyed. They cannot cater for their wards any longer because their sources of income have been destroyed and rendered unattractive. As a result, some of them resort to self help which lead them to fall into the hands of traffickers and kidnappers who promised them prosperous life and employment abroad. But to their chagrin these promises never come to be. Apart from the above mentioned factors, authors, academicians and human rights activists have argued that globalization, and the development of organized crime are important factors which enhances the push factors. ${ }^{3}$. And the confluence of these two factors drives sex industry which is based on and perpetuated by prevailing unequal socially and culturally defined gender and power relations ${ }^{4}$.

Finally, the Sister Florence, Committee for the Support of the Dignity of Women (COSUDOW) maintained that the social problem created in the South-South region Nigeria was as a result of the collapse of the local oil industry in 1980s, pollution and destruction of aquatic life and environmental degradation caused by extensive oil exploration. The Structural Adjustment programme (SAP) imposed by the World Bank and International monetary Fund debt, are also key issues of the push factors ${ }^{5}$.

\section{The Pull or demand Factor}

The Pull or demand factor is vital and has aptly been used to explain root causes of human trafficking. The pull

\footnotetext{
${ }^{1}$ Oyindo, A. J and Brambaifa P. B. (2018) Girl Child Marriage in the Nigerian Society, causes, impacts and mitigating Strategies. World Journal of Social Sciences and Humanities. Vol. 4 no. 2. 105-106. Available at. http://www.sciepub.com/journal/wjssh. Accessed 16/8/2019 2 The Vangaurd Newspapers Feb 8 2019. :

${ }^{3}$ Williams, P. (1999) “ IIlegal Immigration and Commercial Sex- The New Slave Trade . "Trafficking in Woman and Children; A Market Perspective" Transnational organized Crime, Special Issue3-4 London. Routledge publishers p. $202 . \quad$ Available at: https://doi.org/10.4324/9780203044551. Accessed 22/07/2019.

${ }^{4}$ Nurmi, R. (1999) "Mobile Russian Prostitution in Finland," A Paper Presented at the $32^{\text {nd }}$ Triennial Conference of the International Abolitionist federation, Breakdown of Borders, December 2-4. Copenhagen, Denmark.

5 ibid.
} 
factor predominantly refers to the demand for women and young girls by pimps, brothels, miners, massage parlours for commercial sex exploitation. It is also the demand and recruitment of women and young by traffickers for financial gain, sexual exploitation, and domestic work, and other forms of servitude.

Hughes et al argued that hundreds of Nigerian women and girls, hoping to escape poverty, discrimination, and unemployment at home, voluntarily migrate to Europe and America in search of job offers as domestic servants, bar attendants, and waitresses ${ }^{1}$. But upon arrival to their destination countries, many of them discovery to their astonishment that it is not the much-expected "Eldorado" of their dreams, as majority of them found themselves trapped in sex exploitation, and prostitution, coupled with huge debts and compelled work under brutal conditions ${ }^{2}$.

Aronowitz said that the pull factors are those things that influences or attract individual to seek wealth or a better life in other countries ${ }^{3}$. Konig reiterated that immigration laws and policies in destination countries, including policies on migrant labour, migration, and prostitution, and corrupt officials in sending, transit, and destination countries, further contribute to the development of human trafficking and sex trade ${ }^{4}$. The import of this statement is that weak immigration laws contribute to porous borders which pave way for human trafficking and smuggling. Also, certain stringent government policies turn out in most cases to be counterproductive. For example, if immigration requirements are made less flexible, people find all means to circumvent it unlike when it is made to be accommodating and flexible.

Conversely, the legal acceptance of prostitution as a legitimate business is also a reflection of pull factor. For example, prostitution is legalized in some European countries like Italy, Netherland, UK and Ireland. The current Irish state policy on prostitution prohibits pimping i.e. managing and exploiting prostitutes, soliciting sex, living off earning of a prostitute, and brothel keeping, but engaging in transactional sex or prostitution per se, is not a crime for either the client or the prostitute ${ }^{5}$. This has made transportation, recruitment and transfer of trafficked victims an easy business in Nigeria, Europe, and in some other African countries. The pull factor therefore, elicits customer or client's demand for sexual services and employer demand of cheap labour and domestic work. The implications of pull factors are huge to the extent that it has frustrated attempt to suppress and criminalize demand for commercial sex service to be superficial and ineffective one ${ }^{6}$.

To sum up, with the push and pull factors we are able to know the main causes of human trafficking and sex trade. For example, the root causes of human trafficking in Nigeria is the complete disregard of human rights. Women, young girls and also children are termed as objects that can be sold. They are however, sold into slavery, sex trade, forced marriages etc. They are sold as objects for monetary benefits. This is why it has been argued that trafficking in persons is a push and pull factor that both developed and developing countries are guilty of. At this standpoint, we are able to know why trafficking in persons is termed as the second most lucrative business after illicit drug trafficking and arms smuggling. With the low risk of being arrested, prosecuted and sentenced, trafficking is seen today as invincible and complicated to eradicate. In effect, this has increased the rate at which women and young girls are recruited, kidnapped, raped, and sexually exploited. Available evidence has shown that causes of trafficking in developed societies are slightly different in underdeveloped societies. In underdeveloped societies like ours, for example, the pull factor are caused by poor family background, economic problems, ignorance, and prejudice against women and children and the less privileged in society. The prejudiced against women in Nigeria is huge and visible. The push and pull factors put in proper perspectives why trafficking in persons is negative and counterproductive and why countries must collaboratively and simultaneously fight to eradicate the phenomenon.

\section{MODUS OPERANDI OF HUMAN TRAFFICKING IN NIGERIA}

According to European Asylum Support Office (EASO) report, 2015, the Nigeria's human trafficking networks depend considerably on its size and structure ${ }^{7}$. The report showed that the size of organization of networks depends on the size of the operation and the number of women being trafficked, the financial capacity of the groups and how well connected the groups are with immigration officers, travel agents, airline officers and other security personnel at the airport ${ }^{8}$. The more flexible and loose structure of the network the more effective and

\footnotetext{
${ }^{1}$ Hughes, M.D et al (2005), "Coalition Against Trafficking in Women" fact Book on Global Sexual Exploitation. Available at. www.catwpage.net.,S.

${ }^{2}$ Akor, L, (2011) trafficking of Nigeria Women; Causes, Consequences and the Way Forward. Corvinus Journal of Sociology And Social Policy Vol. 2(2) pp.89-110. Available at. http://unipub.lib.uni-corvinus.hu/3141/1/linus_akor.pdf.

${ }^{3}$ Aronowitz, A. (20010 Smuggling and Trafficking in Human beings: The Phenomenon, The markets that drive it and the Organization that Promote it. European Journal on Criminal Policy and research 9 (2) 163-195.

${ }^{4}$ Ilse Konig, ed., Trafficking in Women (Vienna: Federal Chancellery, 1997), 17.

${ }^{5}$ Elis Ward: (2010) Prostitution and The Irish State: From Prohibitionist to A Globalised Sex Trade. Irish Political studies Vol.

25, No. 1 47-65. Routledge. Available at http://www.tandfonline.com/loi/fips20.

${ }^{6}$ Karen E. Bravo: Human Trafficking in the 21st Century: Conceptual Frameworks and Responses

${ }^{7}$ European Asylum Support Office (EASO) report, 2015.available at. https://www.refworld.org/pdfid/5631c0a4.pdf. Accessed 26/07/2019.

${ }^{8}$ EASO Report 2015.
} 
more difficult for the police to neutralize and arrest gang members.

Another method is that the trafficking networks employ a variety of actors that cut across skilled recruiters, travel agents, law enforcement agents, to professional forgers, hackers, fraudsters and those with financial power. Further, UNDOC revealed in its $2005^{1}$ and $2011^{2}$ reports that most networks were not temporary but were wellorganized and relatively solid, formidable, and durable.

Again the UNODC ${ }^{3}$ studies carried on Nigeria's human trafficking gangs revealed that acquaintances, close friends or family members play a major role in the recruitment and transportation of victims to destination countries. Recruitment according to the report, frequently occurs in the victim's own town. And the method is usually characterized by a debt bondage scheme, oath taking before victims travelled to abroad. Victims trafficked to Italy, the Netherlands, Belgium, Spain; France, Sweden etc are forced to pay back inflated smuggling fees (Air Ticket, accommodation, feeding etc). Unfortunately, most of them are heavily exploited and abused by traffickers and eventually afflicted with deadly diseases. However, victims travel to Europe by plane from Lagos and other international airports from West Africa. This movement is made easy usually with the assistance of immigration officers, travel agents and embassy officers. Others can also travel by sea across the Mediterranean and Malta. In the past women would have to be flown in to Europe with fake immigration documents, but recently traffickers subject these women with the threat of force, juju rituals to embark on the dangerous 2,500 mile journey overland through Africa and across Libya before making an equally hazardous crossing by sea to Italy on migrants boats.

The use of force, coercion, violence and intimidation are frequently used to control and put victims in check. For example, in Nigeria and the Balkans-based trafficking rings violence and use of force are commonly used to control victims. The Russian criminal gangs that engaged in human trafficking equally adopt harsh method to control their victims.

Voodoo or juju is also used in the Nigeria human trafficking networks. Voodoo or juju in the Nigerian context is a form of witchcraft existing alongside Christian or Islamic belief. It refers to a variation of ancient West-African religious tradition, in which a priest connected to a voodoo shrine has the power to manipulate outcomes in people's lives ${ }^{4}$. Before travelling out of Nigeria traffickers usually lead recruited women and young girls to ancient shrines where voodoo priests perform rituals, which involve the eating of chicken hearts, superficial cutting of the vitims body with razors and the beheading of goats ${ }^{5}$. Victims go through this elaborate juju rituals to enforce an agreement on them, which states that victims will pay back their enormous transportation money and other debts. The voodoo rituals is harmful, frightening and harrowing to the extent that it prevent victims from running away or disclosing their identity and the identities of traffickers and 'madams ${ }^{6}$, to law enforcement authorities in destination countries. The victims are also warned that their family members could be kidnapped, killed and tortured if they attempt to escape.

The trafficked victims are treated like commodities picked from grocery shops. They are beaten, harassed and abused and intimidated so that they can pay their debts to 'madams' and their traffickers. First, trafficked victims are kept at reception centers. The reception centers acts as a warehouse or clearing house where these trafficked victims are temporary kept for easy background check. Unfortunately, the reception centres are not good places for trafficked young women and girls. Men come to these centers and picked them and drove off. Men picked them up as objects of trade, buy, exploit and resell. Sadly, the centers exposes victims to more exploitation, abuse and physical harm.

At times there are cases of missing persons and these missing persons are usually picked up and driven away to unknown destination. This practice is unacceptable and somewhat callous. It is our argument that the policy of placing Nigerian women in reception centres among thousands of other migrants is rather counterproductive and it helps traffickers to have control of these women and to sexually exploit them more.

Many of these women arrived their destination countries with a whopping debt of about $€ 40,000-€ 45,000$ being expenses for their transport fare from Nigeria to Italy, travel documents, and accommodation. These women and young girls are desperate to leave their country in search of good life in Europe, America, Saudi Arabia and South Africa. These Nigerian women and young girls are forced to become sex tool to Italian Mafia

\footnotetext{
UNODC, Transnational Organized Crime in the West African Region, 2005. p.27. Available at. https://www.unodc.org/pdf/transnational_crime_west-africa-05.pdf.

${ }^{2}$ UNODC: The Role of organized Crime in the Smuggling of migrants from West Africa to the European Union. Available at: https://www.unodc.org/documents/human-trafficking/migrant-Smuggling/Report_SOM_West_Africa_EU.pdf.

${ }^{3}$ UNODC Documents and Data Analysis on Trafficking in Persons. 2010. Available at. https://www.unodc.org/documents/data-and analysis/tocta/2.Trafficking_in_persons.pdf. Accessed 26/07/2019

${ }^{4}$ Van Dijk et al (2006)

${ }^{5}$ Van Dijk, R. (2001) Voodoo on the Doorstep: Young Nigerian Prostitutes and Magic Policing in the Netherlands" in Africa: Journal of the International African Institute Vol. 71 No.4. Edinburgh University Press, Edingurgh. Pp 555-586

${ }^{6}$ The madams are female traffickers that recruit these women with the help of other female accomplice in Nigeria. The madam designs the activities and leads the clandestine networks and she manages victims of prostitution and coordinates victims movement from one European country to another.. The victims are indebted to the madams immediately they reach their destination countries. The debt can only be recovered with the help of Voodoo and juju rituals. The debt range from $€ 40,000-€ 45,000$
} 
as they use them and dump them at will. Human trafficking we must understand is purely gender based phenomenon because victims are women and young girls who are regularly recruited for sexual exploitation and forced labour

Kleemans argued that victims often times cooperate in the terror-induced rituals voluntarily, although under deceptive promises that they will pay back not knowing the huge debt bondage and exploitative nature of what the agreement entails ${ }^{1}$. Nadége was one of those women trafficked and sexually exploited before she managed to escape from the hands of her traffickers. She was just six when she was first raped by a group of neighbours ${ }^{2}$. At 15 she was raped again and had her first abortion. At this stage she became prey to traffickers. A madam she met in Lagos promised her a better life in Europe. The madam promised to get her a waitress job in France. But when she got to France it was not paradise but like from frying pan to fire. She was sexually exploited and at the same time the money she made was paid to the madam and a little was given to her for house rent, food and medical treatment. Unfortunately she could not save for herself nor send money to her families in Edo State Nigeria due to her debts to "madam" and pressure from traffickers. She was coerced to undergo the voodoo and juju rituals before she left Nigeria. She was transported to France and forced into sexual slavery, at $€ 20$ (\$23) per client, to pay off a debt to a female Nigerian pimp popularly called "madam". Nadége, who could not give her real name for safety reasons, grew up in one of the oil producing regions Edo state in Nigeria to be precise ${ }^{3}$.

According to CNN report, Nadège was made to swear an oath at a 'shrine' or 'juju' temple administered by a powerful native doctor called Ayelala, a very popular belief system in Southern Nigeria. (Edo, Delta and Rivers State) This oath put victims under the control of their traffickers and 'madams' with a threat of barrenness and harm to them and their family members if they reveal the identity of their recruiters and traffickers. The European Asylum Support Office ( FASO) informed that recruitment for trafficking to Europe operates and locate their targets in Edo and Delta region of South-South Nigeria. Both states are endowed with huge oil resources, and unfortunately Nadége was born 5 in Edo state Nigeria.

Another case to taste the potency of the voodoo rituals was reported by the National Agency for Trafficking in Persons of Nigeria (NAPTIP).The Agency lamented on how difficult it has been to prosecute traffickers due to the fear put on victims by the voodoo and juju rituals. Victims are also reluctant to report and testify against their 'madams' and traffickers ${ }^{6}$. An Officer of the Agency said that the girls are usually taken to shrines and made to swear an oath of secrecy ${ }^{7}$. The essence of this oath-taking is to instill fear and cause psychological stress on victims. The potency of the voodoo rituals on the victims is philosophically unverifiable and unscientific.

At the destination country also victims are subjected to another set of oath-taking. In effect, the oath restrains them from identifying and testifying against their traffickers in the court of law. The Agency stated that case of Sarah Okoye who was charged with trafficking six girls to Spain for prostitution. NAPTIP reported that the victims refused to appear in court to testify against Sarah Okoye which virtually brought the trail to a halt because victims are afraid of the potency of the oath taken at the juju shrine. This scenario is heartbreaking and this paper proposed at its conclusion what can be done to safe victims of human trafficking from experiencing the psychological trauma of oath taken at the juju shrine.

Similarly, in the case of Constance Omoruyi, trafficked victims were afraid to testify in court for fear of the potency of the oath But conviction was secured because the chief priest who administered the oath testified against the trafficker in court ${ }^{8}$.

The above incidents therefore are testament that voodoo and juju rituals play a very significant role in the increase of human trafficking in Nigeria. Apart from that, voodoo and juju rituals help trafficking rings to perpetuate the act and at the same time remain sophisticate in their mode of operation. The threat of harm, juju ceremonies, voodoo sacrifices, and threat of barrenness are used to keep these women in check and to have psychological control of them. And victims are warned that terrible things will happen to them and their family members if they run away, or fail pay their debts.

\footnotetext{
1 Kleemans, E.R.( 2011). Expanding the Domain of Human trafficking Research: Introduction to the Special Issue on Human Trafficking .Trends in Organized Crime. 14(2-3)148-164. Available at. https://links.springer.com/content/pdf/10.1007\%2Fs12117-011-9138.pdf. Accessed. 06/08/2019

2 The Vanguard October .2018: Paris Park where Nigerian women are forced into Prostitution exposed by CNN.

${ }^{3}$ CNN Report on Nigeria Sex Slaves in Paris, France. Available at: http://edition-m-cnn.com/2018/10/04/africa/paris-nigeria-womentrafficking/index.htm. Accessed on 19/07/2019

${ }^{4}$ Ayelala is a popular chief priest who administers oath of secrecy for business purposes and other fetish requirements in the South-South region of Nigeria.

${ }^{5}$ The European Asylum Support Office ( FASO)

${ }^{6}$ Mojeed, M (2008) Nigeria Voodoo Aids Human Trafficking. Available at

http://lastradainternational.org/lsidocs/Nigeria.pdf. Accessed 29/07/2019.

${ }^{7}$ Ibid.

${ }^{8}$ Mojeed, M (2008) Nigeria Voodoo Aids Human Trafficking. Available at.

http://lastradainternational.org/lsidocs/Nigeria.pdf. Accessed 29/07/2019.
} 


\section{STATISTICS OF TRAFFICKED NIGERIAN WOMEN AND YOUNG GIRLS FOR SEX TRADE IN EUROPE}

Human trafficking is a worrisome phenomenon today and due to our porous borders, immigration regulations, the population of trafficked persons has doubled overtime. And to determine the accurate figure trafficked in each year has been difficult. As such some social scientists have argued that there is no sound methodology to estimate the number of people trafficked and the merit of exiting estimates and reported figures remain disputed. Therefore the statistics of persons trafficked globally reported in this paper may not represent the actual number of persons trafficked probably due to lack of collaborative and simultaneous efforts from countries and difficulty in making victims testify against trackers and their recruiters globally.

The Advocacy Project Nigeria (N.D.) a non-governmental organization revealed that Nigerian women make up 70 per cent of 70,000 African victims of trafficking and that approximately 70 per cent of these women end up in Italy ${ }^{1}$.Again Human Right watch (2001) reported that Nigeria is a destination country for trafficked persons from Ghana, Togo and Benin Republic ${ }^{2}$

Trafficking therefore is a trade which the former UN Secretary-General Late Kofi-Annan called an outrage and a worldwide plague and conducted throughout the world with near impunity ${ }^{3}$. The US report 2012 put the total estimates of trafficked persons at 27 million or more as being enslaved worldwide. The report also shows that trafficking in humans generates huge profit of between US\$7-10 billion annually. In fact it is this huge profit margins that drive criminal gangs to consistently exploit their victims at a higher scale ${ }^{4}$ and this is why the causes and effects of human trafficking are huge and seems insurmountable. The magnitude of human trafficking has made it difficult to determine the number of people trafficked hence the constant recruitment and demand factor victims. For example, an African child taken to the United States might net a trafficker $\$ 10,000-\$ 20,000$ US Dollars 5

In 2000, the Dutch government lifted ban on brothels. The essence is to regulate and legalize prostitution in Netherland. The demerit of this policy outweighs the merit because it increases the number of women and young girls into prostitution and sex trafficking. Voluntary prostitution by prostitutes of legal age was no longer prohibited $^{6}$. The dramatic increase in number of women and young girls patronizing sex trade is becoming complicated the more. As if that is not enough, Italy and Britain have also joined in legalizing prostitution and sex trade as alternative employment outlet for women and probably because of its huge economic gains. It is unfortunate that economic gain was considered above human rights abuses, sexual exploitation of women and health related problem associated with prostitution. Nigeria is underdeveloped and cannot legalize prostitution because we lack standard health system, high level of corruption and weak government institutions and absence of enlightenment and rehabilitation programmes for trafficked victims.

Another statistics showed that in 2014 about 1,500 Nigerian women arrived by sea in Italy and shockingly in 2015 this figure went up to 5,633. The UN's International Organization for Migration (IOM) believes that $80 \%$ of these women are victims of trafficking. As the number of women and young girls continued to increase, there is no consistent effort to scale the number down. As a result this has become a serious global concern to Africa and Europe.

The number and scale of criminal sex trade in Nigerian women is heartbreaking and unprecedented. Before these women were exploited but there was chance that they could pay off their debts to their madams and traffickers and be free. Right now, it is not happening. These girls really are sex slaves and subjected to terrible violence and abuse. The age bracket of these girls is getting younger to 17 or less and they are classified as unaccompanied minors when they are pathetically dropped off the boats.

According to IOM report of July 2018, over 60,000 Nigerians remain trapped in Libya, with $50 \%$ of them hailing from Edo State. In 2014, the International Organization for Migration (IOM, 2014) reported that about 1,500 Nigerian women arrived Italy by Sea. These women have come from Nigeria Edo State where Nigerian gangs of traffickers exploited chronic poverty, women discrimination, government marginalization, communal conflicts, failing educational system, and unemployment.) In 2017, a total of 18,000 Nigerian migrants were recorded to have arrived into Europe via the Mediterranean, 5,400 of which were women ${ }^{7}$

In 2015, a shocking number of 5,633 Nigeria women arrived by sea in Italy. The UN report believes that $80 \%$ of these women were victims of trafficking who were promised of good jobs, higher earnings and good life

\footnotetext{
${ }^{1}$ The Advocacy Project Nigeria (N.D), available at. http://www.advocacy.org/cpage_view/Wocon_html.

${ }^{2}$ Human Rights Watch (2001). Available at. http://www.hrw.org/press 2001/07/trafficking-0712.html.

${ }^{3}$ Annan k (2000) Secretary-General, In Address To ‘Women 2000' Special Session, Says Future of Planet Depends Upon Women. UN Press Release SG/SM/743o.

${ }^{4}$ The US Department of States report 2012

${ }^{5}$ Fitzgibbon, ( ) Modern Day Slavery? The Scope of Trafficking in Persons in Africa, African Security Review, p.12.

${ }^{6}$ Huisman W. and Kleemans E. R. (2014) The Challenges of Fighting Sex Trafficking in the Legalized Prostitution Market of the Netherlands. Journal of Crime Law Social Change. Springer Science-Business Media Dordrecht. No Vol.61(2) p. 216-217. Available at. http://www.HuismanKleemans2014_thechallengesoffightingsextrafficking.pdf.Accessed 29/07/2019.

${ }^{7}$ UNHCR 2018.
} 
in Italy. Some of the victims think that they are coming to Italy to work in Night Clubs, as dancers and entertainers but later discover that they have been trafficked for sex trade and domestic house helps. In fact $80 \%$ of these trafficked women come from Edo, and Delta State respectively. The shocking aspect of it that most of the trafficked victims come from the major oil producing states in Nigeria (Edo, Delta, Akwa Ibom) etc.

In 2003 the United Nations Interregional Crime and Justice Research Institute reported that virtually every Benin Family has one member or the other involved in trafficking as a victim, sponsor, 'madam' or trafficker ${ }^{1}$. This illuminate the fact that human trafficking is not only lucrative enterprise but also a legitimate business for most families in Edo State Nigeria.

In another development, statistics show that West African countries are notorious recruiting and destination ground for traffickers. For instance, countries like, Republic of Benin, Togo, Cote d'Ivoire, Equatorial Guinea, Cameroon, Gabon and Gambia are destination countries where Nigerian women and young girls are held, intimidated, victimized and later transported to Europe for sex trade and forced labour. The trafficked victims were promised good life and higher income abroad before they leave Nigeria but at their different destinations it dawn on them that they are destined to work as commercial sex worker, maids, nannies in affluent families and domestic servants in farm plantation.

The Sister Florence, Committee for the Support of the Dignity of Women (COSUDOW) ${ }^{2}$ reported that Edo girls went to Italy on Visas to work picking tomatoes or work in the farm. This is usually promises and tricks use by traffickers to recruit their victims. The truth of the matter is that these Edo women ended up in prostitution and brothel houses. Some are subjected different kinds of servitude or to modern day slavery. Some came back rich, and became examples of success but others who came back with nothing narrate their horrifying experiences with their "madams' and their traffickers.

In Europe, the story is very pathetic and worrisome. Nigerian women and young girls are not in short supply. They work at brothels, night clubs, and massage parlours while traffickers live on their earnings and at the same time intimidate them. Recent data show that an increasing number of women and young girls seeking asylum in the UK are trafficked victims ${ }^{3}$.As an asylum seeker one is restricted and limited. The right to work is restricted until asylum is granted. One is denied access to social benefits and the success of asylum applications is one in a thousand. It takes long to be processed and during this period of waiting, most Nigerian women go through many harrowing experiences like health problems, abuse, immigration threats by traffickers, exploitation by night clubs, pubs and restaurants.

In the Middle East, the situation is harsh and difficult for Nigeria women who are not Muslims. They face serious religious and immigration restrictions. However, Nigerian women are not deterred by these restrictions because most of them are from Northern region where Islam is dominant. The notion that Northern women are not into prostitution or exempted from sexual exploitation is only but a figment of lies. For example, women and young girls from Kano, Kaduna, Borno, Bauchi, Gombe and Jigawa states are today victims of sexual exploitation and forced labour in Saudi Arabia, Dubai, Turkey, Malaysia, and Syria. The improved immigration record in developed countries has helped to debunk the erroneous impression that women and young girls from Northern Nigerian are not into sex trade and prostitution.

In another report, it is revealed that from March 2002-April 2004, the Saudi Arabia authorities deported 9,952 women and 1,231 underage unaccompanied children ${ }^{4}$. Investigations revealed that the majority of the women deported from Saudi Arabia are from the Northern region of Nigeria ${ }^{5}$. Many have argued that since human trafficking is part of the shadow economy, determining the number of women and young girls who are trafficked is difficult and even the numbers presented have not been accurate ${ }^{6}$. So it is difficult to say how the fight against human trafficking will be won if Nigerian and Italian government are playing lip service over the endemic problem and the socio-cultural implications of trafficking in persons. For example in the streets of Ashi, Turin in Italy, all of the Nigerian commercial sex workers in every night are victims of trafficking. This is just one street in a small city of Turin Italy. This is happening all over the cities of Italy and Europe and shockingly the numbers are increasing daily.

\section{SOCIAL AND HEALTH RELATED CONSEQUENCES.}

No doubt, Nigeria women in Europe if not discovered on time die because of serious health challenges. Many of them especially the young ones are forced to have sex with 10-20 men daily. Some are subjected to sexual

\footnotetext{
${ }^{1}$ The United nations Interregional Crime and Justice Research institute. 2003.

${ }^{2}$ Landinfo ( Country of Origin Information Centre) Trafficking in Women-Fact-Finding Trip to Nigeria ( Abuja, Lagos and benin City). 1226. 3.3 2006, 5/2006. Available at. http://www.refworldorg/pdfid/4980858915.pdf. Accessed.26/07/2019.

${ }^{3}$ Daily Telegraphy March 9, 2001.

${ }^{4}$ Ofuoku.A.U. (2010) Human Trafficking in Nigeria and Its Implications for Food Security. International Journal of Rural Studies (IJRS) Vol.17(1) p.2 Available at: https://www.academia.edu/6963455/human_Trafficking_in_Nigeria_and_its_Implications_for_Food_Security.

${ }^{5}$ Ibid. p. 2

${ }^{6}$ Curtol, F., et al (2004) Victims of Human Trafficking in Italy: A Judicial Perspective. International Review of Victimology. Vol. 11(1). 111141.
} 
servitude, physical violence, ganged raped if they refused, and other forms of exploitation. The outcome is that these women develop serious psychological trauma and risk of deadly diseases.

During the stage of travel and transit in the trafficking process, victims are at risk of starvation, drowning and suffocation due to poor means of transportation, and risk of communicable diseases ${ }^{1}$. The common health consequences of sexual exploitation are sexually transmitted infections, which can cause irreversible complications like infertility, ectopic pregnancy, or in the long run, cervical cancer ${ }^{2}$. Victims equally face physical torture resulting in broken bones, stab wounds, frequent fainting, head injuries, cigarette burns and stress injuries ${ }^{3}$. Bruises, scars and other signs of physical abuse and torture are common with victims of sexual exploitation. Victims are often beaten in areas that will not damage their outward appearance, like their lower back so that victims can remain attractive to their clients.

Other health consequences include: gynaecological problem like chronic pelvic pain, vaginal discharge and pain, pelvic inflammatory disease (PID), unwanted pregnancy and miscarriage ${ }^{4}$. Victims are subjected to physical health symptoms like headache, fatigue, dizziness, back pain, stomach or abdominal pain, difficulty in

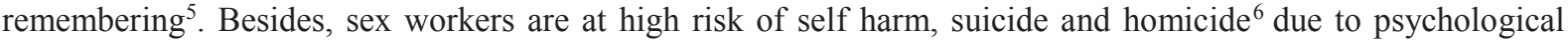
trauma and depression.

Jane Edeki of the African Women Empowerment Group (AWEG) warns that the trafficking of women poses a grave danger to Nigeria women of the high incidence of Human Immune Virus and the deadly Acquired Immune Deficiency Syndrome HIV/AIDS infection common with deported Nigerian women and young girls ${ }^{7}$.Her warning is anchored on the poor health care given to victims and the dearth of health care providers and personnel to administer medications on traumatized victims.

Due to unprotected sexual intercourse which their customers are happy to pay, these women are easily exposed to dreaded diseases like STDs, HIV/AIDS, Hepatitis, and Syphilis. Some are recruited for pornography and bestiality services by their traffickers. And payments of services rendered are paid to recruiters and traffickers while only feeding money is giving to victims.

Overall, UNICEF sum up the social and health related consequences of Nigerian women and young girls trafficked abroad to include loss of lives, increasing prevalence of sexually transmitted diseases, increase in violence and crime rate, increased school drop-out rates, impaired child development, poor national image and massive deportation of Nigerian women.

\section{FAILURE OF THE NIGERIAN GOVERNMENT}

There is no gainsaying the fact that government responses to human trafficking have been poor and uninspiring. The government has been passive because of lack of political will and the corrupt activities of the immigrations officers at the border and sadly judicial corruption. This has contributed to the abysmally low response of the Nigerian government in the fight against human trafficking and sexual exploitation of some Nigerian women and young girls in Europe.

Chapter IV, Art. 34(1) (a)-(c) of the Nigerian constitution1999 that stipulates the prohibition of cruel and inhuman treatment as well as slavery and forced labour against persons has not been effectively implemented due to government nonchalant attitude towards the harm of human trafficking and sex exploitation of Nigerian women abroad. Also social and economic policies of Nigerian government have failed to embrace the realities of human trafficking and forced servitude of our women and young girls both home and abroad. Recently the number of single mothers and divorce cases has continued to rise. Strikingly the legal department and the social welfare personnel can only be seen but not heard. In Nigeria, section 17(2) (e) of the Constitution of the Federal republic of Nigeria, 1999 ( as amended) provides for the independence, impartiality and integrity of the Courts of law and easy accessibility thereto. But today the judicial independence has been eroded by some interested individuals in the trafficking business and as such the judicial system lacks the power to implement and prosecute offenders.

\footnotetext{
${ }^{1}$ Abdulraheem S. and Oladipo A.R (2010) Trafficking in Women and Children: a Hidden Health and Social Problem in Nigeria. International Journal of Social and Anthropology Vol.2(3) pp. 34-39. 5. Available at http://www.academicjournals.org/ijsa. Accessed $29 / 07 / 2019$.

${ }^{2}$ Beyrer C and Stachowiak J. (2003) Health Consequences of Trafficking of Women and Girls in Southeast Asia. Brown J World Affairs. Vol. 10: $\quad$ no $\quad 1 . \quad 106 . \quad$ p. $\quad 10$ Available https://www.justice.gov.il/en/Units/Trafficking/MainDocs/Health_consequences_of_trafficking_women_and_girls.pdf. Accessed 29/07/2019. ${ }^{3}$ Simkhada P. et al. (2018) Health Consequences of Sex Trafficking: A Systematic Review. JMMIHS 4(1) pp. 130-149

${ }^{5}$ Zimmerman et al. (2006) Stolen Smiles; A Summary Report on the Physical and Psychological health Consequences of Women and adolescents trafficked in Europe. London School of Hygiene \& Tropical Medicine 9LSHTM). Available at. http://www.lshtm.ac.uk/php/ghd/docs/stolen smiles.pdf.

${ }^{6}$ Raymond J.G. (1999) Health Effects of Prostitution. In Hughes DM, Roche C (eds). Making the Harm Visible . The Global Sexual Exploitation of Women and Girls .Kingston Rhode Island . Coalition Against Trafficking in Women. New York pp.59-63.

${ }^{7}$ Oshadare, O. T (2004) "The Past and Present Dimension of Slavery in Nigeria" A Paper Presented at the First National Conference of the Faculty of Arts and Humanities, Held at the Kogi State University, Anyigba from $28^{\text {th }}-30^{\text {th }}$ April.
} 
The international law provides the central guiding framework for states combating human trafficking, prostitution and forced labour. And for these international guiding principles to be most effective UN member states should design legal instruments which while consistent with international law, must also be effective and responsive to the fight against human trafficking and such legislation must be tailored to the legal structures and the phenomenon of trafficking as manifested in each state. The Nigerian constitution though comprehensive and drafted under the guiding legal framework of international law, it has been hampered by lack of political will, corrupt judicial officers and corrupt law enforcement agents who are either members of human trafficking gang or have sympathy for human trafficking business. The awareness that some law enforcement officers collude with traffickers discourages victims from reporting the crime. In some cases security officers at the point of departure and entry work in concert with immigration agents, embassies and airline officials to facilitate trafficking. For instance, the Nigerian customs and police officers at our borders purposely keep blind eye to the criminal activities of traffickers. To say our law enforcement agents at our borders are corrupt will be an understatement. They are greedy and morally debased. If the law enforcement agents arrests traffickers and their associates, the level of human trafficking at our borders, airports, seaports and on land will drastically come down. But this is not so.

In 2007 a sting operation carried out at airports in Nigeria, France, Belgium, Italy, Spain, United Kingdom, Ireland and Netherlands resulted in the arrest of 56 Nigerians, including top immigration officials for assisting traffickers and criminal gangs ${ }^{1}$.

To put it bluntly, the combating of human trafficking has been exacerbated by the inability of Nigerian government to implement legislations that deemed human trafficking as a serious crime against humanity for which those involved would be adequately punished. Conversely, the Nigerian government has not fully complied with the international legal instruments that prohibit human trafficking, women discrimination and child labour in different countries. Nigeria in $13^{\text {th }}$ June 1985, ratified the UN Convention on the Elimination of All forms of Discrimination Against Women (CEDAW) ${ }^{2}$. In 2004, Nigeria became a signatory to the Optional Protocol to the Convention on the Elimination of All Forms of Discrimination Against Women ${ }^{3}$. Interestingly, both Conventions were ratified without reservations which mean that the country has agreed to domesticate the two Conventions. In the same vein, the Nigeria NGO working in conjunction with CEDAW reported in 2008 that Nigeria has domesticated the African Charter on Human and People's Rights ${ }^{4}$. It is one thing to ratify a treaty and another thing to implement and enforce the treaty to the letter. On the strength of ratifying CEDAW, Nigerian ought not to be treated as sex objects. Shockingly, Nigerian women are still being discriminated, marginalized, abused, raped, kidnapped and trafficked abroad for sexual exploitation and forced labour. Government ineptitude and empathy to the plight of victims of human trafficking allude to the fact that the Nigerian government responses and measures towards eradicating human trafficking and sexual exploitation are not only narrow but utterly visionless.

The Nigerian government social policies tend not to work in tandem with the Child Rights Act $2003^{5}$ which prohibits early marriages and selling children for prostitution. The minimum marriageable age according to the 1990 Marriage Act is 21 for girls. Shockingly, the Nigeria Federal law is implemented in disregard of the Child Right Act 2003 and the Marriage Act 1990. Young girls are forced into early marriages which results in serious health problems like VVF, abortion, and premature deaths. In fact to date, only a few of the 36 states in Nigeria have started developing provisions to execute the law ${ }^{6}$. This development has made traffickers more formidable and invincible in the recruiting states and destination countries. To further complicate matters, Nigeria has three different legal systems operating simultaneously - civil, customary, and Islamic — and state, it is disgraceful that the Federal government has control only to marriages that took place within the civil system ${ }^{7}$ but unfortunately Nigeria family law system is weak and scarcely do not have control over early marriages.

In an attempt to eradicate human trafficking in the country, the first Nigeria's anti-trafficking act; Trafficking in Persons (Prohibition) Law Enforcement and Administration Act came into force on $14^{\text {th }}$ July 2003. On the strength of this Act, the National Agency for the Prohibition of Trafficking in Persons and Other related Matters (NAPTIP) was established on 26 August 2003 and was saddled the responsibility of preventing,

\footnotetext{
1 Bower, M.M. (2012) Room For Improvement: Nigeria's Approach to Trafficking; IMPOWR Prints. Available at. http://www.impowr.org/sites/default/files/vjrnl/IMPOWR -Room For Improvement.pdf. Accessed 22/09/2018.

${ }^{2}$ UN Treaty website available at http://treaties.un.org/Pages/Viewdetails.aspx?src=Treaty\&mtdsg_no=IV-8\&chapter=4\&lang=en. Accessed $24 / 07 / 2019$.

${ }^{3}$ Ibid.

${ }^{4}$ The Nigeria CEDAW NGO Coalition Shadow Report, Submitted to the $41^{\text {st }}$ Session of the United Nations Committee on the Elimination of All Forms of Discrimination Against Women holding at the United Nations Plaza New York, between June 30-July 18 2008. Available at. http://www.baobabwomen.org/Shadow\%20report.pdf. Accessed 24/07/2019.

${ }^{5}$ The Nigeria Child Right Act 2003 created by the National Assembly.

${ }^{6}$ Country of Origin Information (CORI ) Thermatic Report Nigeria: Gender and Age.. December 2012.Available at. www.coricenter.net. Accessed 27/07/2019

${ }^{7}$ Ibid.
} 
protecting, and persecuting traffickers and other criminal gangs in the trafficking business ${ }^{1}$. NAPTIP's functions include the identification and reception of victims, sheltering, counseling and training, family tracing, return and repatriation, integration, empowerment and follow-up mechanisms ${ }^{2}$. Also victims are provided with the opportunity to vocational training, basic education, business management skills and financial empowerment to enable them start small scale businesses while others are reunited with their families and absorbed into the society for a new start in life The question is do NAPTIP in the real sense perform all these critical functions? Your guess is as good as mine. The truth of the matter is that NAPTIP cast a shadow of itself. NAPTIP was the brainchild of a private member bill sponsored by Women Trafficking and Child Labour Eradication Foundation (WOTCLEF). It was a non-profit organisation founded by Titi Atiku wife of former Vice President, Alhaji Atiku Abubakar. It is not in doubt today that the objectives and vision of the founder has been eroded by the present government.

NAPTIP is today handicapped and frustrated because of inconsistent government policies. The agency is poorly funded and poorly managed. Recently 5, 000 Nigerians were stranded in Mali due to poor funding from the present government. Again, hundreds of Nigerians in Libya

As a result the management of this agency is left at the mercy of people who not properly trained for counseling and rehabilitation programmes. Appointment of principal heads of the NAPTIP has been illconceived and individuals without in-depth knowledge of what counseling and rehabilitation programme entails have been appointed on the basis of their political affiliation and not on their merit. As a result, the agency has performed abysmally low in tackling the challenges of trafficking in persons for sex trade and forced labour.

Apart from the problem of unqualified personnel of NAPTIP, the agency is poorly funded considering the huge demands and needs of victims of human trafficking. The NGOs that ought to compliment the efforts of NAPTIP have not been encouraged by government policies. It is sad that government do not give them monetary support to compliment the efforts of the NAPTIP. It is probably only in Nigeria that government do not fund or compliment NGO's effort to combating human trafficking. The Trafficking in Persons Report by USDOS, added that the Nigerian government has been nonchalant in implementing formal procedures for the return and reintegration of victims and returnees of human trafficking from abroad ${ }^{3}$. It is also only in Nigeria that legislation work only in theory but not in practical. For example, in theory the penalties for human trafficking is imprisonment but in Nigeria many traffickers avoid prison by paying fines ${ }^{4}$ or offering bribe to law enforcement agents and some lawyers. It is our believe that the anti-human trafficking strategies can achieve considerable and appreciable results when Nigerian government passes a legislation that would restrict the powers given to judges to offer fines in lieu of stiff penalties or imprisonment to traffickers. Unless this measure is put in place the concerted efforts towards combating human trafficking in Nigeria will continue to be a charade.

Apart from that, the human trafficking is not only a criminal justice problem rather it involves broader social issues which include labour, urban management and foreign policies. International mechanisms which the government ratified without reservation and national legal framework are yet to be fully implemented due to lack of political will and unnecessary bureaucracy.

Moreover, legislations designed to fight human trafficking in Nigerian has not gone beyond criminalizing traffickers. The rights of immigrants and the workers that assist victims to speak out their ordeal have not been taken into consideration by the Nigeria government.. Ehrenreich and Hochschild maintained that any policy designed to fight human trafficking must extend beyond criminalizing traffickers to reinforce the rights of immigrants and workers ${ }^{5}$. Ristoanovic added that for specific case of the trafficking of women and young girls for the purposes of sexual exploitation that prostitution must be included in the legal normative framework of each country ${ }^{6}$.

Barry in his contribution stated that prostitution should be criminalized ${ }^{7}$ whilst Kempandoo opined that prostitution should be regulated as a form of employment ${ }^{8}$. Unfortunately, Nigeria is not fit enough and does not have what it takes to regulate prostitution as a form of employment because a lot of women will be vulnerable and victims to traffickers. Moreover, the level of corruption is high and the government institutions saddled with

\footnotetext{
${ }^{1}$ NAPTIP Fact Sheet at p. 5

${ }^{2}$ NAPTIP Fact Sheet at p. 6

${ }^{3}$ USDOS 2014.p. 297

${ }^{4}$ Cherti, et al. (2013) Beyond Borders. Human Trafficking from Nigeria to the UK. Institute for Public Policy Research. Available at. http://www.ippr.org/assets/media/images/media/files/publication/2013/01/nigeriatrafficking_Jan2013_10189.pdf. Accessed 24/07/2019.

${ }^{5}$ Ehrenreich, Barbara; Hochschild, Arlie Russell (2002), Global Woman: Nannies, Maids and Sex Workers in the New Economy. London: Granta Books.

Konig, Ilse (1997) Trafficking in Women ed. Vienna; Federal Chancellery, p. 17.

${ }^{6}$ Ristanovic, V.N. (2003) Sex Trafficking: The Impact of War, Militarism and Globalization in Eastern Europe. Michigan Feminist Study Vol.

17. Issue title: Gender and Globalism. Available at. http://hdl.handle.net/2027/spo.ark5583.0017.001. Accessed 23/07/2019.

${ }^{7}$ Barry, Kathleen (1995), The Prostitution of Sexuality. New York: New York University Press.

${ }^{8}$ Kepadoo, Kaala, Fro Moral Pai to Gloal Justie: Chagig perspectives on trafficking, in Kamala Kempadoo (ed.), Trafficking and Prostitution

Reconsidered. New Perspectives on Migration, Sex Work, and Human Rights. Boulder, Colorado: Paradigm Publisher
} 
responsibility to fight human trafficking are nothing but shadow of themselves. Interestingly, Nigeria is an oilrich country, and endowed with huge mineral resources and human capital, unfortunately the country is today one of the poorest nation in African continent. The country is currently undergoing serious economic quagmire, political instability and huge insecurity problems, lack of adequate health facilities, unemployment and underemployment, kidnapping for ransom, rape, women marginalization, religious mayhem and official corruption. The huge resources derived from oil have not reflected in the lives of Nigerian citizen. This has largely reflected in the problem of human trafficking and sex exploitation of Nigerian women and young girls.

Nigeria has ratified many International legal Instruments such as: the United Nations Conventions on the Declaration of Human Rights (1948): the United Nations Conventions on Elimination of All Forms of Discrimination Against Women (1979): the United Nations Convention on the Rights of the Child (1989): the trafficking in Persons (Prohibition) Law Enforcement and Administration (2003), Palermo Protocol and Convention on the Elimination of All Forms of Discrimination Against Women (CEDAW). Shockingly, human trafficking have continued to rise and victims are constantly being sexually exploited, abused, traumatized, and socially castigated ${ }^{1}$.

It is our view in this paper that if successive Nigerian government has utilized her huge oil resources appropriately, incessant cases of kidnapping and trafficking of Nigerian women and young girls to Europe for sex trade and forced labour would have been avoided. Many of them would be gainfully employed if the government had invested the huge oil resources in education and poverty alleviation programmes, establishment of industries, funding of universities, health system and in job creation. The problem of sex trafficking in Nigeria would have been reduced to its barest minimum if these women and girls are gainfully employed and oil resources equitably distributed. But this is not so. The true position is that our women and young girls are recruited, trafficked abroad for sexual exploitation and forced labour. Many are violated; discriminated, alienated, sexually abused and forced into early marriages, scam marriages, forced prostitution to help family members financially. Shockingly, the present Nigerian government still pretend as if human trafficking and modern day slavery is not a serious problem at all. We cannot continue like this and as such something drastic needs to be done well on time to avoid the devastating effects of trafficking of Nigerian women and young girls for commercial sexual exploitation in Europe.

\section{WHAT CAN BE DONE}

This paper examines trafficking of Nigeria women and young girls into Europe for sex trade and forced labour with a view to highlighting the push and pull factors. The paper address issues like definition problems, modus operandi of traffickers, social and health related consequences and the failure of Nigeria government. Two major findings of this paper are economic problems and government incompetence and visionless policies. These two findings contribute largely to the push and pull factors. The country's poverty level is high and United Nations Sustainable Development Goal (SDG) Report June 2018, showed that 86.9 million (about 50\%) Nigerians are living in an extreme poverty ${ }^{2}$. As a way, the Nigeria government should urgently address the problem of unemployment and poverty now otherwise the complexities of human trafficking will continue to be a red flag to the socio-political, economic and cultural milieu of our country. Our observations from this paper showed that there is no end in sight of the scourge of human trafficking. This is because the Nigerian government lacks the political and the moral persuasion to eradicate the problem of trafficking of Nigerian women. However, we are optimistic that the pangs of poverty, unemployment, corruption, discrimination and abuse of womenfolk and all vestiges of push and pull factors could be eliminated if government is sincere, transparent and committed in the war against trafficking in persons.

Arising from the aforementioned findings and observations, the paper makes the following germane recommendations as a way of combating the phenomenon of human trafficking of Nigeria women and young girls for sex trade and forced servitude into Europe:

i. Current researches have shown that poverty, huge unemployment rate, widening inequalities are the major drivers of the incidence cases of human trafficking of Nigerian women and young girls abroad for sexual exploitation and forced labour. To nip in the bud these problems, the present Nigerian government should continue to make concerted towards eliminating trafficking in persons and at the same time partnership with international organization like the UN, IOM and possibly NGOs to help in the fight against the main causes of trafficking of Nigeria women and young girls for sexual servitude. Nigeria government should also device means of reducing poverty rate and high level of unemployment among Nigerian youths.

ii. The problem of ignorance, high illiteracy level and lack of awareness has also been responsible for the

\footnotetext{
1 Jungudo, M. M (2014) Gender and human Rights Implications of Women Trafficking in Northern Nigeria. Mediterranean Journal of Social Sciences MCSER Publishing, Rome-Italy. Vol.5 No.26. Available at. http://www.HUMAN\%20TRAFFICKING/5265-20459-1PB\%20(1).pdf

${ }^{2}$ United Nations Sustainable Development Goal (SDG) Report June 2018.
} 
trafficking of Nigerian women for forced sexual servitude. This paper therefore recommends strategies for increasing awareness and understanding among professional and the public, children and adults on the occupational hazards of trafficking for sexual exploitation. Victims and survivors should be well informed, tutored, counseled and encouraged to identify their 'madam' and traffickers in criminal ring.

iii. There is urgent need to strengthen the law against human trafficking. Chapter IV, Art. 34(1) (a)-(c) of the Nigerian Constitution1999 should be amended in such a way that traffickers and other criminal elements will be adequately punished and deterred.

iv. Nigerian government should create a special courts and fact finding committees to adjudicate and prosecute trafficking offences. Judges appointed to handle trafficking offences shall be of impeccable character and pedigree.

v. Nigerian government should also establish more interventions programme centres for evaluating current and future programme that will facilitate social services for the reception, protection, enlightenment campaigns, rehabilitation strategies and reintegration of victims and survivors so as to prevent possible re-trafficking of already trafficked persons.

vi. There is equally urgent need to create a digital information-sharing platform to promote communication and coordination among providers, and professionals in the care sector.

vii. Nigeria government can respond to human trafficking and sex trade through bilateral agreements between destination countries like Italy, Spain, Netherlands, France, Libya, Benin, and the United Kingdom. The bilateral agreement will help in strengthening international legal instrument against trafficking in persons for sexual servitude.

\section{CONCLUSIONS, AND THE WAY FORWARD}

The way forward here is that the Nigerian government should respond adequately to the overriding factors of poverty, porous borders, corruption, systemic gender discrimination and violence against women. Trafficking in persons will only be minimized if the Nigerian government initiates a policy that will reduce the poverty level of Nigerians and at the same time wage war on corruption. The war on corruption should start with the law enforcement agents at our borders and corrupt law enforcement officers must be adequately punished to serve as a deterrent to others. For example, once traffickers and recruiters noticed that immigration officers are not likely to take bribe from them, definitely they would be discouraged to operate in Nigeria.

Importantly, the Nigerian government should provide enough funds for NAPTIP while complimenting the efforts of NGOs and other Charity Organizations that provide professional and social services to victims, returnees, and young girls that have suffered sexual exploitation. There should be increased opportunities for economic advancement so that Nigeria women and young girls will not be interested to seek employment and good life abroad. At the same time, the Nigerian government should invest in education and other social programmes that will improve the status of women in our society. Finally, the health related consequences of human trafficking and sex trade is spreading like wide fire and as a result, Nigerian government should prioritized the health conditions of deportees, victims and survivors of human trafficking by providing adequate health care facilities to them so that dreaded diseases like HIV/AIDS will be detected and prevented at the early stage. These measures will go a long way in stemming the tide of trafficking of Nigerian women and young girls for sex trade and forced servitude in Europe.

\section{BIBILOGRAPHY}

Abdulraheem S, Oladipo AR. Trafficking in women and children: a hidden health and social Problem in Nigeria. International Journal of Social Anthropology. 2010;2 (3):34- 39.

Akor, L. (2011) Trafficking of Women in Nigeria: Causes, Consequences and the Way Forward. Corvinus Journal of sociology and Social Policy Vol 2(2) Abailable at http://unipub.lib.unicorvinus.hu/3141/1/linus_akor.pdf. Accessed 28/07/2019.

Bales, K. (2005) Understanding Global slavery, Berkeley University of California Press. p. 462

Barry, Kathleen (1995) The Prostitution of Sexuality. New York: New York University Press.

Beyrer C, Stachowiak J. Health consequences of trafficking of women and girls in Southeast Asia. Brown J World Affairs. 2003; 10:105.

Bower, M.M. (2012) Room For Improvement: Nigeria's Approach to Trafficking; IMPOWR Prints. Available at. http://www.impowr.org/sites/default/files/vjrnl/IMPOWR__ -Room_For Improvement.pdf. Accessed $22 / 09 / 2018$

Bruinsma et al (1999) Organized Crime and Trafficking Women from Eastern Europe in the Netherlands' Transnational Organized crime, 4 pp. 105-118.

Burkhater H. (2003) Sex Trafficking and The HIV/AIDS Pandemic. http://www.physiciansforhuman.rights.org/Library/2003-25.html. Accessed 12/05/2015

Cherti, et al. (2013) Beyond Borders. Human Trafficking from Nigeria to the UK. Institute for Public Policy 
Research.

Available http://www.ippr.org/assets/media/images/media/files/publication/2013/01/nigeriatrafficking_Jan20 13_10189.pdf.

Curtol, F., Decarli, S., Di Nicola, A., \& Savona, E. U. (2004). Victims of Human Trafficking in Italy: A Judicial Perspective. International Review of Victimology, 11(1), 111-141.

Ehrenreich, Barbara; Hochschild, Arlie Russell (2002), Global Woman: Nannies, Maids and Sex Workers in the New Economy. London: Granta Books.

Guruam S. and Sing Harbilas: (2013) Human Trafficking: A Conceptual Framework. Journal of Siberian Federal University, Humanities \& Social Sciences 4 p. 485 . Available at http://journal.sfukras.ru/en/article/9712. Accessed 20/06/2018.

Hosken, G. (2007) Human Trafficking a Huge problem in SA. The Independence

Huisman, W, and Kleemans, E. R (2014) The Challenges of Fighting Sex Trafficking in the Legalized Prostitution Market of the Netherlands.

James, C., and Atler, S. (2003) Trafficking of Young Women in Arvanitakis (ed.) Highly Affected Rarely Considered; The International Youth parliament Commission's Report on The Impacts of Globalization on Young People'.Oxfam International Parliament Sydney. p.71-82.

Jungudo, M. M (2014) Gender and human Rights Implications of Women Trafficking in Northern Nigeria. Mediterranean Journal of Social Sciences MCSER Publishing, Rome- Italy. Vol.5 No.26.Available at. http://www.HUMAN\%20TRAFFICKING/5265- 20459-1-PB\%20(1).pdf

Kempadoo, K. ,(2005) From Moral Panic to Global Justice: Changing Perspectives on Trafficking, in Kamala Kempadoo (ed.), Trafficking and Prostitution Reconsidered. New Perspectives on Migration, Sex Work, and Human Rights. Boulder, Colorado: Paradigm Publisher

Karen, E. Bravo, (2007) Exploring the Analogy between Modern Trafficking in Humans and the Transatlantic Slave Trade, 25 B. U. International Law Jurist. 207, 213.

Katerere, F. (2007) Human Traffickers Thrive in Mozambique. The Citizen. Available at. http://www.citizen.co.za/index/article.aspx?pDesc=35379,1,22. Accessed 23/07/2019

Maggy, L., (2007) Human Trafficking, William Publishing, Oregon USA.p.3

Miers, S. (2003)Slavery in the Twentieth Century; The Evolution of a Global Problem. Walnut Creek, CA: Alta Mira Press.

Ould, D. (2004) Trafficking and International Law in C. Van Den Anker (ed). The Political Economy of New Slavery. Basingstoke: Palgrave Macmillan.

Perera, A. (2011), Human Trafficking, New Delhi: Global Vision Publishing House India.

Poulin, R. (2004) Globalization and Sex Trade, Trafficking and Commodification of Women and Children, Ca Women's Stud. 22. 38-43.

Sassen, S. (2002) Women's Burden: Counter-Geographies of Globalization and the Feminization of Survival. Nordic Journal of international Law 71 (2) 255-274.

Simkhada P. et al. (2018) Health Consequences of Sex Trafficking: A Systematic Review. JMMIHS 4(1) pp. 130149 .

Thozama Mandisa L, and Lanier, M (2012) An Integrated Theoretical Framework to Describe Human Trafficking of Young Women and Girls for Involuntary Prostitution. Journal of public Health-Social and Behavioral Health. www.intechopen.com. Accessed 20/06/2018.

Truong, T.,and Angels, M. (2005) Searching for the Best Practices to Counter Human Trafficking in Africa; A focus on Women and Children. UNESCO: Project to Fight Human Trafficking in Africa.

Ristanovic, V.N. (2003) Sex Trafficking: The Impact of War, Militarism and Globalization in Eastern Europe. Michigan Feminist Study Vol. 17. Issue title: Gender and Globalism. Available at. http://hdl.handle.net/2027/spo.ark5583.0017.001. Accessed 23/07/2019.

Zimmerman et al. (2006) Stolen Smiles; A Summary Report on the Physical and Psychological Health Consequences of Women and Adolescents Trafficked in Europe. London School of Hygiene \& Tropical Medicine 9LSHTM). Available at. http://www.lshtm.ac.uk/php/ghd/docs/stolen smiles.pdf. Accessed $27 / 07 / 2019$

\section{UN /EU DOCUMENTS/OTHERS}

The Council of the European Union (2010) Council Framework Decision of 19 July 2002 to Combating Trafficking in Human Beings, 2002/629JHA. Available at. http://eur-lex.europa.eu/lexUrServ/lexUrServ.do?

United Nations high Commissioner For Human Rights 2002 (UNOHCHR)

The United Nations Protocol to Prevent, Suppress and Punish Trafficking in Persons especially Women and Children. The UN General Assembly Resoultion 55/25 of $15^{\text {th }}$ November 2000. Available at. Https://www.ohchr.org/en/professionalinterest/pages/protocoltraffickingin persons.aspx

The United nations Interregional Crime and Justice Research institute. 2003. 
US Department of States in its document titled "Trafficking in Persons Report 2010

United Nations Sustainable Development Goal (SDG) Report June 2018.

UN Treaty website available at $\mathrm{http}$ //treaties.un.org/Pages/Viewdetails.aspx? src=Treaty\&mtdsg_no=IV8\&chapter=4\&lang=en. Accessed 24/07/2019.

The Nigeria CEDAW NGO Coalition Shadow Report, Submitted to the $41^{\text {st }}$ Session of the United Nations Committee on the Elimination of All Forms of Discrimination Against Women holding at the United Nations Plaza New York, between June 30-July 18 2008. Available at. http://www.baobabwomen.org/Shadow\%20report.pdf. Accessed 24/07/2019.

National Agency for the Prohibition of Trafficking in Persons ( (NAPTIP)

Fact Sheet at p. 5

NAPTIP Fact Sheet at p. 6

Daily Telegraphy March 9, 2001.

Landinfo ( Country of Origin Information Centre) Trafficking in Women-Fact-Finding Trip to Nigeria ( Abuja, Lagos and benin City). 12-26. $3.3 \quad 2006, \quad 5 / 2006$. Available at. http://www.refworldorg/pdfid/4980858915.pdf. Accessed.26/07/2019. 